\section{Mode of Action and Biological Properties of the S-(Methylcarbamyl) Methyl 0,0- Dimethyl-Dithiophosphate}

Previous investigations have demonstrated that S-(methylcarbamyl) methyl O,O-dimethyl-dithiophosphate (I), which possesses a peculiar insecticidal and systemic activity, very effectively controls the olive fly (Dacus oleae Gmel.) $)^{1}{ }^{2}$, the olive moth (Prays oleellus F.) ${ }^{3}$, the cherry fruit fly (Rhagoletis cerasi L. $)^{4}$ and many other important pests. It was of interest, therefore, to investigate the metabolic behaviour and biological properties of this insecticide.

Experiments carried out by means of paper chromatography have demonstrated that oxidation of compound (I) by potassium permanganate and by hydrogen peroxide produces some derivates. Among them one component has been isolated, purified (by means of 100-tube Craig countercurrent distribution) and identified: the S-(methylcarbamyl) methyl O,O-dimethyl-thiolphosphate (II). The low $R_{F}$ values of the spots and other evidence suggest that the other products of the oxidation of compound (I) are due to hydrolysis (possibly O,O-dimethyl dithioand thiol-phosphoric acids). Metallic ions $\left(\mathrm{Fe}^{3+}\right.$ $\mathrm{Cu}^{2+}, \mathrm{Zn}^{2+}$ catalyse the conversion of dithiophosphate (I) to thiolphosphate (II).<smiles>CNC(=O)CSP(=S)(OC)OC</smiles><smiles>CNC(=O)CSP(=O)(OC)OC</smiles>

The same transformation has been shown to occur, at least partially, in vivo in plants such as broad beans, after root absorption of the insecticide, and in cherries, picked from sprayed trees; and in vitro in animal tissues, by incubating the insecticide (I) with mouse liver. Other derivatives (possibly products of hydrolysis), besides the thiol metabolite (II), from hydrogen peroxide oxidation of compound (I), were not found in the paper chromatographed tissues.

A gradual reduction in the amount of compound (II), obtained by chemical synthesis and applied to broad beans and cherries in the same conditions as insecticide (I), was demonstrated by paper chromatography and bioassay, but no evidence was obtained on the conversion of this compound to other derivates.

Toxicological researches indicate that the thiolphosphate (II) is a much stronger esterase inhibitor than the dithiophosphate (I) : 185 times as effective as bovine cholinesterase inhibitor and 883 times as effective as house fly (Musca domestica L.) cholinesterase inhibitor. Nevertheless, compound (II) is only four times as toxic as (I) to mice by oral administration.

The insecticidal activity of both substances (I) and (II), tested on 11 species of insects, is nearly equal ; the small differences boing related to species and strges of insects and methods of testing. This suggests also that insects may metabolize the dithiophosphate (I) to thiolphosphate (II). On the other hand, the two substances possess different acaricidal activities : compound (II) is about 38 times as toxic as (I) to adults of Paratetranychus pilosus Can. and Fanz.
Finally, studies on systemic properties have been conducted. Both products, when applied to roots, stems or leaves of beans are absorbed and translocated to other parts of the plants in amounts lethal to the test mites (adults of Tetranychus telarius L.) feeding on untreated parts of the same plants. Furthermore, both compounds penetrate from the outside to the inside of fruits and exert a lethal effect on some species of fruit-eating larvæ.

Detailed results will be published elsewhere.

$$
\text { R. SANTI }
$$

P. DE Pietrei-Toneli

Istituto Ricerche Agrarie, Società Montecatini,

Signa, Florence. Nov. 28.

'Pellegrini, G., L'Ital. Agric., 92, 747 (1955).

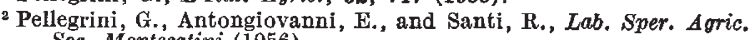
Soc. Montecatini (1956).

${ }^{3}$ Antongiovanni, E., Olivicolt., XI, 5, 1 (1956).

4 de Pietri-Tonelli, P., L'Ital. Agric., 93, 49 (1956).

\section{a-Tocopherol and Hyaluronidase in vivo}

THe description of exudative diathesis in chicken by $D^{2}{ }^{1}$ indicates a considerable degree of capillary damage. In a further publication ${ }^{2}$ he attributed this to a deficiency of $\alpha$-tocopherol.

Reports $^{3,4}$ on the interaction of $\alpha$-tocopherol and hyaluronidase suggested to me that, apart from its anti-oxidant activity, $\alpha$-tocopherol might be involved in the protection of inter-cellular cement substance. Thus, in the condition described by Dam, the exudation could be due to the effect of hyaluronidase acting on the inter-cellular cement substance of the capillary walls and surrounding supporting tissues without the restraining influence of adequate $\alpha$-tocopherol.

We divided twelve chickens into three groups of four each. Group I was fed a basal ration low in vitamin $\mathrm{E}$ and containing 17 per cent protein, $3 \cdot 3$ per cent fat, 1.3 per cent calcium, 0.8 per cent phosphorus and 0.5 per cent added sodium chloride; group 2 received the same ration plus 14 x.U. vitamin E/lb. fed as added 'Rovimix' (F. Hoffman, La Roche et Cie.) ; group 3 a normal commercial ration. After 5 weeks on these diets two birds in each group were injected intraperitoneally with a commercial brand of hyaluronidase 'Rondase' (Evans Medical Supplies, Ltd.). Each bird received 6,000 r.v. daily for 7 days. On the eighth day the birds were killed together with the control uninoculated birds, and Table 1 shows the results of post-mortem examination.

\begin{tabular}{|c|l|c|}
\hline \multicolumn{2}{c}{ Table 1 } \\
\hline Group & $\begin{array}{c}\text { Control birds } \\
\text { (no hyaluronidase) }\end{array}$ & \multicolumn{1}{c|}{$\begin{array}{c}\text { Birds injected with } \\
\text { hyaluronidase }\end{array}$} \\
\hline 1 & $\begin{array}{l}\text { Slight hæmorrhages } \\
\text { in muscles } \\
\text { Normal } \\
\text { Normal }\end{array}$ & $\begin{array}{l}\text { Hæmorrhages and advanced } \\
\text { exudative diathesis } \\
\text { Normal } \\
\text { Slight hæmorrhages in muscles }\end{array}$ \\
\hline 3
\end{tabular}

These results indicate that in vivo $\beta$-tocopherol can act as a regulator of hyaluronidase activity.

\section{Elizabeth A. Irving:}

Institute of Medical and Veterinary Science, Frome Road,

Adelaide. Nov, 20.

1 Dam, H., and Glavind, J., Nature, 142, 1077 (1938).

a Dam, H., and Glavind, J., Nature, 143, 810 (1939).

${ }^{3}$ Miller, W. H., and Dessert, A. M., Ann. N.Y. Acad. Sci., 52, 167 (1949).

4 Cascio, J., Amer. J. Ophthalmol., 36, 278 (1953). 